\title{
Inflammatory Pseudo-tumour Orbitae (PTO): An Atypical Manifestation of Giant Cell Arteritis (GCA)
}

\author{
M. Hittinger $\cdot$ A. Berlis $\cdot$ K. Pfadenhauer
}

\section{List of Abbreviations}

$\begin{array}{ll}\text { AION } & \text { Anterior ischaemic optic neuropathy } \\ \text { CCDS } & \text { Colour-coded duplex sonography } \\ \text { CRP } & \text { C-reactive protein } \\ \text { CT } & \text { Computed tomography } \\ \text { CWDS } & \text { Continuous-wave Doppler sonography } \\ \text { ESR } & \text { Erythrocyte sedimentation rate } \\ \text { GCA } & \text { Giant cell arteritis } \\ \text { MRI } & \text { Magnetic resonance imaging } \\ \text { OS } & \text { Left eye } \\ \text { PION } & \text { Posterior ischaemic optic neuropathy } \\ \text { PTO } & \text { Pseudo-tumour orbitae } \\ \text { sc } & \text { Without correction } \\ \text { TAB } & \text { Temporal artery biopsy } \\ \text { TIA } & \text { Transient ischaemic attack }\end{array}$

\section{Introduction}

Giant cell arteritis (GCA) commonly involves the orbital arteries [10]. However, pseudo-tumour orbitae (PTO), defined as non-infectious orbital inflammation of unknown origin, is an uncommon presentation of this disease. Thus

\footnotetext{
M. Hittinger, MD $(\bowtie) \cdot A$. Berlis, $\mathrm{PhD}$

Department of Diagnostic and Interventional Radiology and Neuroradiology, Augsburg Hospital,

Stenglinstraße 2,

86156 Augsburg, Germany

e-mail: Markus.Hittinger@klinikum-augsburg.de

K. Pfadenhauer, MD

Department of Neurology, Augsburg Hospital,

Stenglinstraße 2,

86156 Augsburg, Germany
}

far, only few reports have been published in the literature [5]. Hence, the present case aims to encourage physicians to integrate GCA in the differential diagnosis of PTO because this disease requires immediate therapy due to the risk of blindness [6].

\section{Case Presentation}

A 78-years-old male patient suffering from arterial hypertension presented in July 2013 to the neurologic department of a regional hospital after he had experienced two intermittent episodes of right facial and upper-extremity weakness. A native cranial computed tomography (CT) scan showed neither intracranial bleeding nor acute ischaemic lesions but a small patchy subcortical hypodensity within the left parietal lobe and moderate white matter gliosis. Suggesting transient ischaemic attacks (TIAs), the patient received acetylsalicylic acid $(100 \mathrm{mg} /$ day $)$ and ramipril $(2.5 \mathrm{mg} /$ day $)$.

Two weeks later, another attack of transient dysarthria and paraesthesia occurred. While the native cranial CT did not show any new parenchymal lesions, supra-aortic CT angiography demonstrated an approximately $50 \%$ proximal stenosis of the right vertebral artery. The orbits were unremarkable. Colour-coded duplex sonography (CCDS) of the cranial arteries revealed no significant stenosis, as well. There were no signs of inflammation in the laboratory investigation. Suspecting epileptic seizures, an anticonvulsive treatment with levetiracetam ( $1.5 \mathrm{~g} /$ day $)$ was started, and no further attacks occurred.

In October 2013, the patient presented a third time to the hospital with new-onset temporal headache, neck pain, jaw claudication and an ongoing visual deterioration of the left eye (OS). GCA was already suspected by the general practitioner, and steroid therapy was started at a daily dose 
Fig. 1 a, b Neighbouring axial contrast-enhanced T1-weighted images show diffuse infiltration of the left orbit
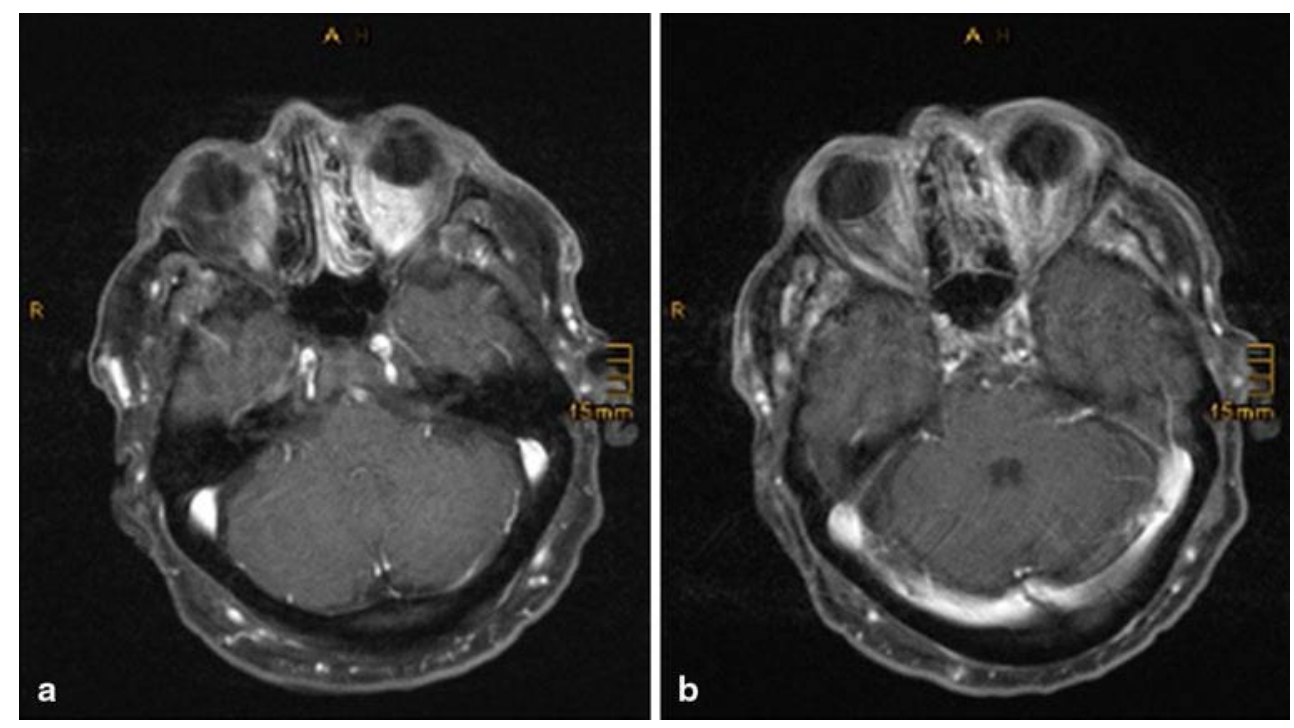

of $40 \mathrm{mg}$ of prednisolone 4 days before admission to the regional hospital. On admission, erythrocyte sedimentation rate and serum $\mathrm{C}$-reactive protein levels were raised to $64 \mathrm{~mm}$ after the first hour and $13 \mathrm{mg} / \mathrm{dl}$ (normal value: $<0.5 \mathrm{mg} / \mathrm{dl}$ ), respectively. Suspecting an infectious disease, Unacid at a daily intravenous dose of $1.5 \mathrm{~g}$ was administered. When body temperature increased to $38.8^{\circ} \mathrm{C} 2$ days later, prednisolone was stopped. As the ophthalmic pathology was the leading diagnostic finding, magnetic resonance imaging (MRI) of the orbits was performed, and the patient was transferred to the eye department of our hospital for further investigations.

MRI demonstrated a diffuse inflammation of the left orbit (Fig. 1). Pathologic enhancements aside from the left orbit were not detected. Furthermore, additional T2*-weighted images of the brain displayed several cortical microbleeds and a circumscribed older subcortical haemorrhage of the left parietal lobe, at the side of the patchy hypodensity that was first described in CT. The white matter showed pointshaped and patchy gliosis.

The ophthalmologic investigation at our hospital revealed a substantial reduction of the visual acuity OS ( 0.1 without correction (sc)), and there was a monocular hemianopsia. The left face and orbit were swollen. The OS showed proptosis but no chemosis. Both temporal arteries were slightly indurated but not painful on palpation. Further ophthalmologic and neurologic investigation was unremarkable.

CCDS revealed extensive wall lesions of the temporal arteries with low echogenicity. The carotid arteries showed arteriosclerotic plaques without high-grade stenosis. CWDS of the supratrochlear arteries demonstrated a reduced leftsided flow. Transorbital ultrasonography was not performed.

Due to continuously elevated serum markers of inflammation despite antibiotic treatment and further suspecting GCA, we restated and increased prednisolone therapy 2 days after interruption to a dosage of $100 \mathrm{mg} /$ day. Temporal artery biopsy (TAB) confirmed the suspected diagnosis.

Clinical and laboratory signs of inflammation rapidly decreased within few days. Antibiotic treatment was stopped. Visual acuity OS improved to $0.25 \mathrm{sc}$. MRI investigation 7 days after transfer to our hospital demonstrated advanced restoration of the left orbit with residual enhancement of the intraorbital fat tissue (Fig. 2).

\section{Discussion}

GCA-associated PTO has occasionally been described in the literature $[1,2,4,5,7,8]$. Imaging findings often appear indistinct and infiltrative (Table 1). Orbital tumours are typically caused by inflammation, infection or neoplasia. TAB, failing only in two cases to our knowledge $[5,8]$ (Table 1), is required to establish the correct diagnosis (Table 1). In one patient with negative TAB, GCA could be demonstrated by orbital biopsy [5]. In clinical practice, steroid therapy should be immediately started even in ambiguous cases because it can improve various inflammatory conditions (e.g. Wegener's granulomatosis, GCA, idiopathic pseudotumour) as well as neoplasia (e.g. lymphoma) [9].

Our case is striking because the patient shows a combination of symptoms that are rather uncommon in GCA. Despite the diffuse intraorbital enhancement in MRI, fundoscopy was normal. Therefore, visual deterioration was attributed to a posterior ischaemic optic neuropathy (PION). The typical orbital manifestation of GCA is the anterior ischaemic optic neuropathy (AION) due to an obstruction of the posterior ciliary arteries [3]. AION displays a pallor oedema of the optic nerve head that can be recognized by fundoscopy and typically produces altitudinal visual defects [4] but no hemianopsia. 
Fig. 2 Contrast-enhanced T1weighted axial (a) and coronal (b) images after 7 days of high-dose prednisolone therapy: intraorbital enhancement has nearly completely resolved
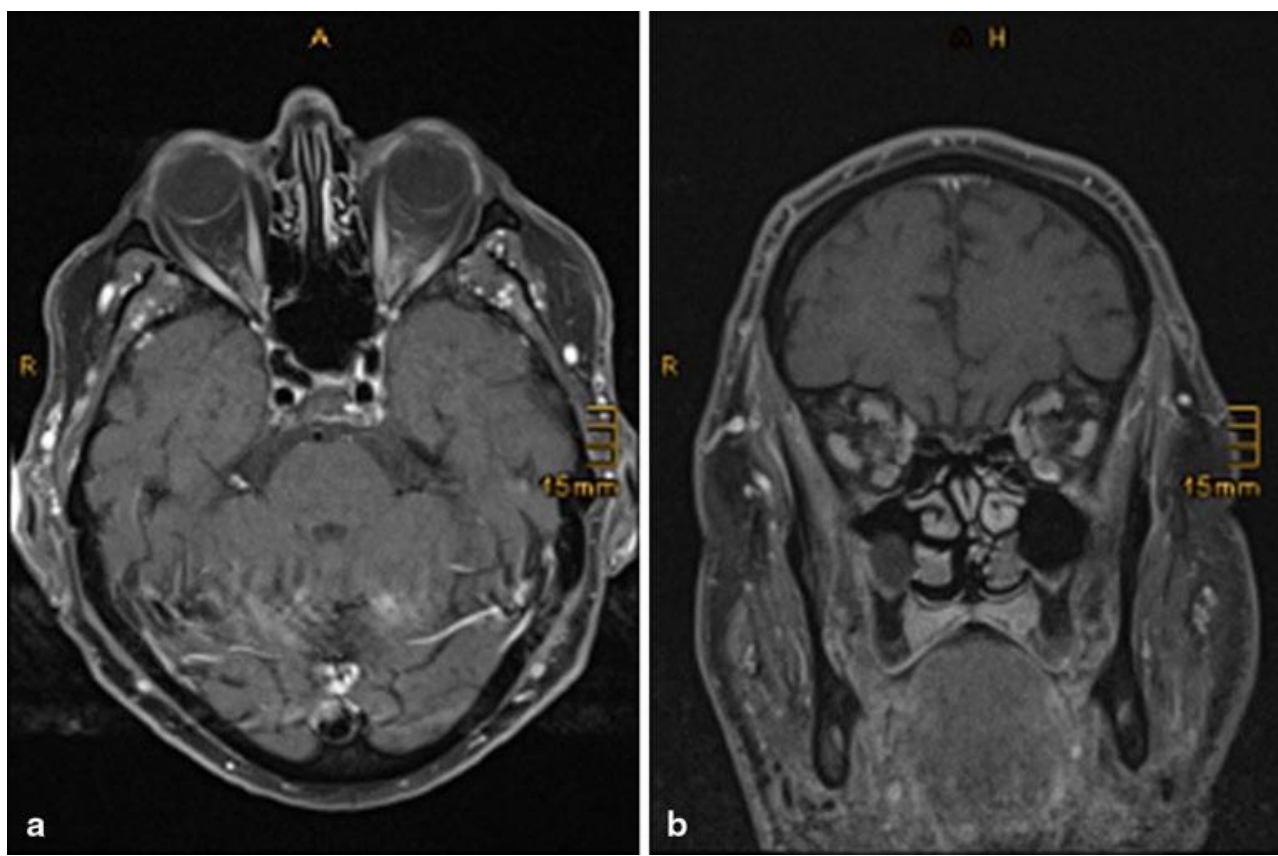

Table 1 Summary of orbital giant cell arteritis manifestations in recent literature

\begin{tabular}{|c|c|c|c|c|c|}
\hline Author/year & Age (years)/sex & Orbital signs & Imaging & Diagnosis/treatment & Outcome \\
\hline $\begin{array}{l}\text { De Heide and } \\
\text { Talsma/1999 }\end{array}$ & 73/Female & $\begin{array}{l}\text { Binocular diplopia } \\
\text { Ophthalmoplegia of the } \\
\text { right inferior rectus muscle }\end{array}$ & $\begin{array}{l}\text { CT: exophthalmos of } \\
\text { the right eye, slightly } \\
\text { increased thickness of } \\
\text { the inferior rectus muscle }\end{array}$ & $\mathrm{TAB}+/$ steroids & Free of symptoms \\
\hline \multirow[t]{4}{*}{$\begin{array}{l}\text { Lee et al./2001 } \\
\text { (four cases) }\end{array}$} & 70/Male & $\begin{array}{l}\text { Right eye: proptosis, visual } \\
\text { loss, pain }\end{array}$ & $\begin{array}{l}\text { MRI: bilateral orbital } \\
\text { infiltration }\end{array}$ & $\begin{array}{l}\text { Orbital bi- } \\
\text { opsy+/steroids, } \\
\text { cyclophosphamide }\end{array}$ & No light perception \\
\hline & 69/Male & $\begin{array}{l}\text { Binocular vertical diplopia, } \\
\text { bilateral proptosis }\end{array}$ & $\begin{array}{l}\text { MRI: enhancement of } \\
\text { the orbit and optic nerve } \\
\text { sheath }\end{array}$ & $\mathrm{TAB}+/$ steroids & Improved \\
\hline & 72/Female & $\begin{array}{l}\text { Right eye: pain, proptosis, } \\
\text { conjunctival injection }\end{array}$ & $\begin{array}{l}\text { MRI: signal alteration in } \\
\text { the right medial rectus } \\
\text { muscle }\end{array}$ & $\begin{array}{l}\text { TAB }+/ \text { steroids } \\
\text { intravenously }\end{array}$ & Improved \\
\hline & 82/Male & $\begin{array}{l}\text { Right eye: episcleritis, } \\
\text { proptosis, oedema }\end{array}$ & $\begin{array}{l}\text { MRI: enlargement of the } \\
\text { right-sided extraocular } \\
\text { muscles }\end{array}$ & $\mathrm{TAB}+/$ steroids & Improved \\
\hline Islam et al./2003 & 72/Female & $\begin{array}{l}\text { Right eye: proptosis, mildly } \\
\text { swollen optic disc, choroi- } \\
\text { dal perfusion delayed and } \\
\text { minimized }\end{array}$ & $\begin{array}{l}\text { CT: inflammation around } \\
\text { both optic nerves, infil- } \\
\text { tration of the right apical } \\
\text { fatty tissue }\end{array}$ & $\begin{array}{l}\text { TAB+/steroids } \\
\text { intravenously }\end{array}$ & Improved \\
\hline $\begin{array}{l}\text { Garcia-Porrua } \\
\text { et al./2003 }\end{array}$ & 65/Male & Left eye: amaurosis fugax & $\begin{array}{l}\text { MRI: collateral circula- } \\
\text { tion around the left optic } \\
\text { nerve }\end{array}$ & $\mathrm{TAB}+/$ steroids & Improved \\
\hline Puerto et al./2007 & 69/Female & $\begin{array}{l}\text { Right eye: visual acuity } \\
\text { reduction, exophthalmos, } \\
\text { lacrimation }\end{array}$ & $\begin{array}{l}\mathrm{CT} / \mathrm{MRI} \mathrm{a}^{\mathrm{a}} \text { : slight distal } \\
\text { thickening of the inferior } \\
\text { and lateral rectus muscle }\end{array}$ & $\begin{array}{l}\text { TAB }+/ \text { steroids } \\
\text { intravenously, } \\
\text { cyclophosphamide }\end{array}$ & Complete recovery \\
\hline $\begin{array}{l}\text { Reddi and } \\
\text { Vollbracht/2013 }\end{array}$ & $83 /$ Female & $\begin{array}{l}\text { Right eye: visual acuity } \\
\text { reduction, lacrimation }\end{array}$ & $\begin{array}{l}\text { MRI: right optic nerve } \\
\text { and surrounding fatty } \\
\text { tissue enhancement }\end{array}$ & TAB-/steroids & $\begin{array}{l}\text { Improved; relapse with } \\
\text { bilateral vision loss after } \\
\text { stopping steroid therapy } \\
\text { with only partial improve- } \\
\text { ment after re-established } \\
\text { steroid therapy }\end{array}$ \\
\hline
\end{tabular}

MRI magnetic resonance imaging, $C T$ computed tomography, TAB temporal artery biopsy

${ }^{a}$ First investigation with $\mathrm{CT}$ and follow-up investigation with MRI 
The close relation between the cerebrovascular symptoms and the diagnosis of GCA points to a causal link and a possible large artery manifestation of GCA [6]. However, normal serum markers of inflammation and inconspicuous CCDS at that time make inflammatory TIAs very unlikely. For the same reason, we suggest that the cortical microbleeds, the circumscribed older subcortical haemorrhage of the left parietal lobe and the proximal stenosis of the right vertebral artery should be attributed to cerebral amyloid angiopathy and atherosclerosis, respectively.

Taken together, we present a remarkable case of histopathologically proven GCA. The leading finding in imaging was diffuse left orbital infiltration causing a PION. Although orbital infiltration comprises a broad spectrum of different diseases (e.g. Grave's disease, lymphoma, phlegmonia) that are, in part, more frequent than GCA, GCA should be generally implicated in the differential diagnoses due to the risk of further neuro-ophthalmological ischaemic complications if diagnosis of GCA is missed. Based on the nine cases of the literature (Table 1) and the present case, it has to be concluded that PTO due to GCA bears an increased risk of ischaemic neuro-ophthalmological complications, including loss of vision in four, amaurosis fugax in one and ophthalmoplegia in two patients.

Acknowledgement The authors thank Thomas Witton-Davies (Department of Radiology, Nuclear Medicine and Neuroradiology, Klinikum München-Harlaching) for reading the manuscript and Yilmaz Koeroglu (Department of Ophthalmology, Augsburg Hospital) for providing his clinical expertise.

Conflict of Interest On behalf of all authors, the corresponding author states that there is no conflict of interest.

\section{References}

1. De Heide LJ, Talsma MA. Giant-cell arteritis presenting as an orbital pseudotumor. Neth J Med. 1999;55:196-8.

2. Garcia-Porrua C, Pego-Reigosa R, Armesto V, Gonzalez-Gay MA. Neovascularization around the optic nerve in giant cell arteritis. Arthritis Rheum. 2003;49:737-8.

3. Geiger J, Ness T, Uhl M, Lagrèze WA, Vaith P, Langer M, Bley TA. Involvement of the ophthalmic artery in giant cell arteritis visualized by 3T MRI. Rheumatology (Oxford). 2009;48:537-41.

4. Islam N, Asaria R, Plant GT, Hykin PC. Giant cell arteritis mimicking idiopathic orbital inflammatory disease. Eur J Ophthalmol. 2003; 13:392-4.

5. Lee AG, Tang RA, Feldon SE, Pless M, Schiffman JS, Rubin RM, Rao N. Orbital presentations of giant cell arteritis. Graefes Arch Clin Exp Ophthalmol. 2001;239:509-13.

6. Nesher G. Neurologic manifestations of giant cell arteritis. Clin Exp Rheumatol. 2000;18:S24-6.

7. Puerto B, Noval S, Veiga C, Contreras I, Mateos E. [Apical orbital inflammation in giant cell arteritis]. Arch Soc Esp Oftalmol. 2007;82:47-9.

8. Reddi S, Vollbracht S. Giant cell arteritis associated with orbital pseudotumor. Headache. 2013;53:1488-9.

9. Wasmeier C, Pfadenhauer K, Rosler A. Idiopathic inflammatory pseudotumor of the orbit and Tolosa-Hunt syndrome - are they the same disease? J Neurol. 2002;249:1237-41.

10. Wilkinson IM, Russell RW. Arteries of the head and neck in giant cell arteritis. A pathological study to show the pattern of arterial involvement. Arch Neurol. 1972;27:378-91. 